Pendas : Jurnal IImiah Pendidikan Dasar, ISSN Cetak : 2477-2143 ISSN Online : 2548-6950 Volume III Nomor 2, Desember 2018

\title{
POLA ASUH ORANG TUA TENTANG PENDIDIKAN SEKS KEPADA SISWA KELAS RENDAH (PENELITIAN KUALITATIF DI SD NEGERI BATU CEPER 1 KOTA TANGERANG)
}

\author{
Christina Destaliani ${ }^{1}$, Asih Rosnaningsih ${ }^{2}$, Rizki Zuliani ${ }^{3}$ \\ 1,2,3PGSD Universitas Muhammadiyah Tangerang \\ ${ }^{1}$ christinadestaliani@yahoo.co.id
}

\begin{abstract}
The purpose of this study was to describe the parenting style about sexual education in low grade students in SD Negeri Batu Ceper 1 Kota Tangerang. thhis study was conducted qualitatively using case study approach. There were three children chosen as samples; they were three grade students. The samples were taken purposively after the researcher conducted the initial screening. Each student represents different types of parenting styles they acquired at home. They are authoritarian, authoritative, and authoritative tends to be permissive. The instruments used in data collections are observation, interview, and documentation. The result drew several conslusions relating to the parenting styles on their sexual education: 1) authoritarian parents always exercise control and demand compliance, 2) authoritative parents are willing to guide the child but give freedom of expression, and, 3) authoritative tends to be permissive parents willing to guide the child but lack of control.
\end{abstract}

Keywords : Low Grade Students, Parenting Styles, Sexual Education

\begin{abstract}
ABSTRAK
Tujuan penelitian ini adalah untuk mendeskripsikan pola asuh orang tua tentang pendidikan seks pada siswa kelas rendah di SD Negeri Batu Ceper 01 Kota Tangerang. Penelitian ini dilakukan dengan pendekatan kualitatif tipe studi kasus pada tiga keluarga yang menerapkan pola asuh yang berbeda. Sampel pada penelitian ini adalah tiga siswa kelas 3 SD dan 3 orang tua siswa tersebut yang diambil dari teknik purposive sampling dan diperkuat oleh hasil screening awal. Instrumen yang digunakan pada pengumpulan data yaitu observasi, wawancara, dan dokumentasi. Hasil penelitian ini menunjukkan bahwa dalam menerapkan pendidikan seks kepada anak: 1) Orang tua otoritarian selalu melakukan kontrol dan menuntut kepatuhan, 2) Orang tua otoritatif mau memandu anak tetapi memberikan kebebasan berekspresi, dan 3) Orang tua otoritatif cenderung permisif mau memandu anak tetapi kurang melakukan kontrol.
\end{abstract}

Kata Kunci: Pola Asuh Orang Tua, Pendidikan Seks, Siswa Kelas Rendah

\section{A. Pendahuluan}

Keluarga merupakan kelompok paling sederhana yang terbentuk melalui ikatan dua orang dewasa yang berlainan jenis, yang bertindak sebagai orang tua, kemudian di anugerahi anak-anak. Orang tua memiliki tugas dalam menjaga dan 
Pendas : Jurnal Ilmiah Pendidikan Dasar, ISSN Cetak : 2477-2143 ISSN Online : 2548-6950 Volume III Nomor 2, Desember 2018

memelihara pertumbuhan serta perkembangan anak-anak mereka. Sedangkan seorang anak bertugas mentaati, menghormati serta menjaga nama baik orang tua dan keluarga.

Tanggung jawab mengasuh anak adalah tugas kedua orang tua. Pernyataan tersebut sesuai dengan Undang-Undang Nomor 20 tahun 2003 tentang Sistem Pendidikan Nasional Bab IV bagian kedua tentang Hak dan Kewajiban Orang Tua Pasal 7 ayat 2 yaitu, "Orang tua dari anak usia wajib belajar, berkewajiban memberikan pendidikan dasar kepada anaknya". Berdasarkan Undang-Undang tersebut dapat dikatakan bahwa orang tua berperan dalam mengasuh anak agar siap menghadapi masa depannya.

Di zaman yang telah modern seperti sekarang ini peran orang tua dalam mengasuh anak sangatlah penting terutama pola asuh yang berkaitan dengan pendidikan seks karena informasi tentang penyimpangan seksual belakangan ini sudah mulai menyerang lingkungan anak-anak melalui akses internet, siaran televisi, gadget, majalah, video serta pengaruh teman sebaya bahkan orang dewasa terdekat. Namun nyatanya tidak sedikit orang tua yang mengabaikan tumbuh kembang anak-anak mereka tanpa pola asuh yang baik dan benar sehingga menyerahkan semua pendidikan pada sekolah, termasuk pendidikan tentang seks itu sendiri.

Pendidikan seks pada hakikatnya tidak hanya berbicara tentang hubungan intim antara pria dan wanita akan tetapi juga tentang kesehatan dan perkembangan emosi. Pendidikan seks yang dimaksud disini adalah pendidikan seks yang akan membentuk kepribadian seseorang menjadi lebih matang dan akan bertanggung jawab dalam menggunakan seksualitasnya. Maka pendidikan seks sebenarnya bukanlah hal yang tabu dan dapat dibicarakan orang tua pada anakanaknya sejak dini. Sayangnya, masih banyak orang tua yang memiliki anggapan negatif terhadap pendidikan seks.

Belakangan di negeri ini permasalahan mengenai seks yang menyentuh lingkungan anak khususnya anak sekolah dasar dapat dikatakan sangat memprihatinkan. Seperti yang peneliti temui pada wawancara awal penelitian dengan dewan Guru di SD Negeri Batu Ceper 
Pendas : Jurnal IImiah Pendidikan Dasar, ISSN Cetak : 2477-2143 ISSN Online : 2548-6950 Volume III Nomor 2, Desember 2018

1 Kota Tangerang dimana sampai saat ini sekolah tidak pernah menyediakan pendidikan seks yang diberikan secara khusus baik bagi dewan guru, seluruh staff kependidikan, orang tua serta siswasiswinya. Pemberian pendidikan seks hanya dilakukan bersamaan dengan pelajaran IPA pada kelas 5 dan 6 , sedangkan bagi siswa kelas rendah tidak ada pendidikan seks yang sesuai dengan usia perkembangan mereka, pendidikan seks dirasa cukup dengan pembiasaan penanaman pendidikan agama saja, padahal persoalan dan penyimpangan seks dapat datang dan menyentuh lingkungan siswa dari berbagai usia. Tidak ada pula bimbingan konseling bagi siswa, tempat dimana siswa dapat mengadu pertanyaan pribadinya tentang permasalahan seks. Selain itu, masih ada anggapan yang salah mengenai pendidikan seks bagi anak kelas rendah yang dianggap masih terlalu dini untuk menerima pendidikan seks padahal pendidikan seks bagi anak seharusnya diberikan sejak dini sesuai dengan psikologi dan usianya.

Melihat kurangnya upaya pendidikan seks yang diberikan oleh sekolah kepada anak, maka sangat pantas jika orang tua harus lebih peduli terhadap pendidikan seks untuk anak sesuai dengan pola asuh yang diterapkannya. Berdasarkan permasalahan yang ditemui oleh peneliti diatas, peneliti tertarik untuk mengangkat permasalahan tersebut dalam suatu penelitian dengan judul "Pola Asuh Orang Tua tentang Pendidikan Seks kepada Siswa Kelas Rendah (Penelitian Kualitatif di SD Negeri Batu Ceper 1 Kota Tangerang)".

\section{B.Landasan Teori}

Pola asuh orang tua merupakan pola perilaku yang dianggap paling tepat oleh orang tua sehingga diterapkan pada anak-anak mereka. Definisi pola asuh orang tua lebih jelas dituturkan oleh Djamarah (2014) yang mengatakan bahwa pola asuh adalah "Upaya orang tua yang konsisten dan persisten dalam menjaga dan membimbing anak dari sejak dilahirkan hingga remaja" (h. 51). Pendapat tersebut serupa dengan pengertian pola asuh orang tua menurut Tim Penggerak PKK Pusat (1995) yaitu "Pola asuh orang tua adalah usaha orang tua dalam membina anak dan membimbing anak baik jiwa maupun raganya sejak 
Pendas : Jurnal IImiah Pendidikan Dasar, ISSN Cetak : 2477-2143 ISSN Online : 2548-6950 Volume III Nomor 2, Desember 2018

lahir sampai dewasa (18 tahun)" (Pandawa Care Foundation, 2016). Lebih lengkap lagi Dariyo (2013) mengemukakan bahwa "Pola asuh orang tua ialah upaya aktif dalam mendidik, mengajar, membina, dan mengarahkan sikap, perilaku, perbuatan, maupun tindakan anakanak agar sesuai dengan nilai-nilai, etika, dan norma sosial masyarakat" (h. 137). Dari beberapa definisi diatas, dapat disimpulkan bahwa pola asuh orang tua adalah upaya orang tua dalam mendidik, membimbing, dan mengarahkan sikap, perilaku, maupun pengetahuan anak yang disampaikan dalam bentuk interaksi maupun pola perilaku agar sesuai pada nilai-nilai yang dianggap paling tepat oleh orang tua serta norma yang berlaku di masyarakat sejak lahir hingga dewasa.

Dalam penerapannya, pola asuh orang tua terbagi menjadi tiga macam. Menurut Diana Baumrind (1971, 1996b; Baumrind \& Black, 1967) macam-macam pola asuh tersebut adalah, 1) Pola Asuh Otoritarian (Authoritarian), yaitu pola asuh yang menekankan kepatuhan dan kontrol. penerapan pola asuh otoritarian ini akan menghasilkan anak yang cenderung menarik diri dari orang lain, tidak percaya diri, serta cenderung merasa tidak puas karena seringkali hal yang dilakukannya adalah keinginan orang tua bukan keinginan dirinya sendiri; 2) Pola Asuh Permisif (Permissive), yaitu pola asuh yang menekankan ekspresi diri dan pengaturan diri sendiri, penerapan pola asuh ini akan menghasilkan anak yang kurang matang karena tidak adanya tujuan yang hendak dicapai; dan 3) Pola Asuh Otoritatif (Authoritative), yaitu pola asuh orang tua yang menghargai individualitas anak tetapi juga menekankan batasan-batasan social, penerapan pola asuh ini akan menghasilkan anak merasa aman dan dicintai, serta merasa puas karena dapat mengeksplorasi kemampuan dirinya. (Papalia, Old \& Feldman, 2009:410).

Berdasarkan teori Baumrind tersebut, dalam penelitian ini pola asuh yang akan diteliti adalah pola asuh otoritarian, permisif, dan otoritatif. Dimana yang pertama, pola asuh otoritarian adalah pola asuh yang cenderung didominasi oleh aturan serta hukuman yang banyak dari orang tua kepada anaknya. Kedua, pola asuh asuh permisif adalah pola asuh yang cenderung 
Pendas : Jurnal Ilmiah Pendidikan Dasar, ISSN Cetak : 2477-2143 ISSN Online : 2548-6950 Volume III Nomor 2, Desember 2018

didominasi oleh kebebasan anak dalam berekspresi tanpa adanya batasan-batasan sosial yang jelas tentang bagaimana sebenarnya perilaku yang diharapkan orang tua dari anak. Ketiga, pola asuh otoritatif yaitu pola asuh yang mencakup peran orang tua dan juga anak. Mereka saling menghargai individualitas namun tetap memiliki standar peraturan yang jelas dan tujuan yang hendak dicapai.

Pendidikan seks sebenarnya bukanlah pendidikan yang mengajarkan anak untuk berhubungan seksual, jauh dari pandangan itu Chomaria (2012) mengemukakan bahwa "Pendidikan seks adalah pemberian informasi dan pembentukan sikap serta keyakinan tentang seks, identitas seksual, hubungan, dan keintiman" (h. 15). Sedangkan menurut Novi (2015), "Pendidikan Seks usia dini adalah pemahaman bagi anak untuk mulai mengenal identitas diri dan keluarga, mengenal anggota-anggota tubuh mereka, serta dapat menyebutkan ciri-ciri tubuh mereka masing-masing serta pemahaman akan lawan jenisnya dan pemahaman untuk menghindarkannya dari kekerasan seksual” (h. 143). Lebih lengkap
Abduh, \& Wulandari (2016) mengemukakan bahwa "Pendidikan seks merupakan upaya pengajaran, penyadaran, dan penerangan tentang masalah-masalah seksual yang diberikan pada anak, dalam usaha menjaga anak terbebas dari kebiasaan yang tidak Islami serta menutup segala kemungkinan ke arah hubungan seksual terlarang" ( $h$. 405). Dari paparan tersebut dapat disimpulkan bahwa Pendidikan seks adalah proses pemberian informasi kepada anak tentang identitas seksual, pengenalan organ reproduksi dan perawatannya serta hubungan anak dengan orang lain yang bertujuan untuk menghindarkannya dari kekerasan sekual serta segala kemungkinan yang mengarah pada hubungan seksual terlarang.

Pada penelitian ini, sasaran pendidikan seks difokuskan pada anak usia sekolah dasar kelas rendah. Upaya pendidikan seks yang dapat diberikan oleh orang tua kepada anak pada tahap tersebut disampaikan oleh Chomaria (2012) yaitu yang pertama, beri perlakuan sesuai dengan jenis kelamin anak. Kedua, kenalkan bagian tubuh anak dan fungsinya dengan jelas serta 
Pendas : Jurnal Ilmiah Pendidikan Dasar, ISSN Cetak : 2477-2143 ISSN Online : 2548-6950 Volume III Nomor 2, Desember 2018

ajari pula cara membersihkan alat kelaminnya dengan benar. Ketiga, beri tahu bagian tubuh yang boleh atau tidak boleh disentuh dan beri tahu pula jenis sentuhan yang pantas dan tidak pantas bagi anak. Keempat, seleksi media yang dikonsumsi anak (h.19-47).

\section{Metode Penelitian}

Pendekatan yang digunakan pada penelitian ini menggunakan pendekatan kualitatif dengan metode studi kasus (case study). Menurut Denzin, \& Lincoln (1994) penelitian kualitatif didefinisikan sebagai "Suatu proses penelitian untuk memahami masalah-masalah manusia atau sosial dengan menciptakan gambaran menyeluruh dan kompleks yang disajikan dengan kata-kata, melaporkan pandangan terperici yang diperoleh dari para sumber informasi, serta dilakukan dalam latar (setting) yang alamiah." (Mawardi, 2016:15).

Pengambilan sample pada penelitian ini menggunakan purposive sampling dan snowball sampling untuk menentukan jumlah sampel yang akan dijadikan narasumber. Purposive sampling adalah teknik pengambilan sampel dengan pertimbangan tertentu sedangkan snowball sampling adalah teknik pengambilan sampel yang pada awalnya jumlahnya sedikit, lamalama menjadi besar (Sugiyono, 2010, h. 300$)$.

Jenis metode yang digunakan dalam penelitian ini adalah metode penelitian Studi Kasus. Menurut Creswell (2012) penelitian kualitatif studi kasus merupakan, "Salah satu jenis penelitian kualitatif dimana peneliti melakukan eksplorasi secara mendalam terhadap program, kejadian, proses, aktifitas, terhadap satu atau lebih orang" (Sugiyono, 2014:229). Teknik pengumpulan data pada penelitian ini menggunakan instrumen observasi, instrumen wawancara, dan juga dokumentasi yang ditujukan kepada orang tua sebagai subjek penelitian, dan anak dari masing-masing orang tua guna menambah,mengkonfirmasi, dan menegaskan hasil penelitian. Penelitian ini juga melewati tahapan screening awal, dimana pada tahap tersebut dilakukan penyebaran angket yang diisi oleh siswa, untuk mengetahui pola asuh yang diterapkan oleh orang tua siswa kelas 3A di SD Negeri Batu Ceper 1 Kota Tangerang serta menyaring pola asuh yang relevan dengan penelitian. 
Pendas : Jurnal IImiah Pendidikan Dasar, ISSN Cetak : 2477-2143 ISSN Online : 2548-6950 Volume III Nomor 2, Desember 2018

Teknik analisis data pada penelitian ini mengacu pada teori yang dikemukakan oleh Miles dan Huberman (1984) yang menyatakan bahwa "Aktivitas dalam analisis data kualitatif dilakukan secara interaktif dan berlangsung secara terus menerus sampai tuntas, sehingga datanya jenuh" (Adiputra, 2011). Dalam analisis data hasil penelitian terdiri dari beberapa tahap, yaitu: reduksi data, penyajian data (display data), dan verifikasi data (verification).

\section{Hasil dan Pembahasan}

Berdasarkan hasil screening awal yang dilakukan melalui penyebaran angket pada siswa kelas 3A di SD Negeri Batu Ceper 1 Kota Tangerang diperoleh data mengenai pola asuh orang tua sebagai berikut:

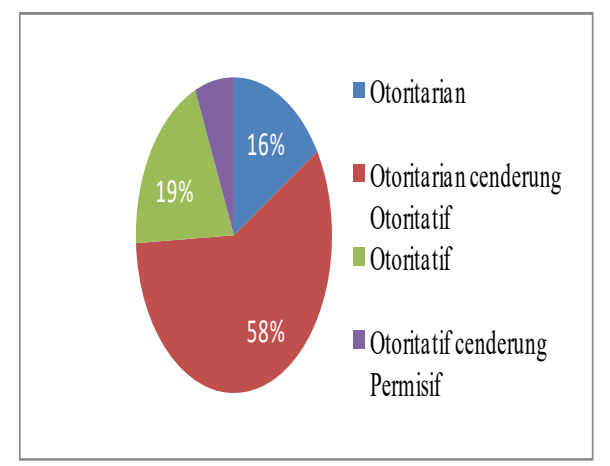

Gambar 1

Hasil screening awal pola asuh orang tua kelas $3 \mathrm{~A}$
Dari total sampel 31 siswa, ditemukan bahwa rata-rata pola asuh orang tua siswa kelas 3A SD Negeri Batuceper 1 Kota Tangerang adalah pola asuh Otoritarian cenderung Otoritatif dengan jumlah 18 orang dan presentase mencapai 56,25\%. Kemudian, 6 orang tua lainnya menerapkan pola asuh Otoritatif dengan presentase 18,75\% sedangkan hanya 5 orang tua siswa yang menerapkan pola asuh Otoritarian dengan presentase sebesar $15,625 \%$, dan sisanya 2 orang tua siswa menerapkan pola asuh Otoritatif cenderung Permisif dengan presentase sebesar $6,25 \%$.

Tidak ditemukan pola asuh permisif (murni) pada orang tua siswa kelas 3 SD Negeri Batu Ceper 1 Kota Tangerang pada skor akhir angket seluruh siswa kelas $3 \mathrm{~A}$, karena sesuai dengan teori yang dikemukakan oleh Nasution (1993) mengenai karakteristik siswa Sekolah Dasar kelas rendah, juga termasuk anak usia sekolah dasar kelas 3 SD sedang berada pada tahap dimana ia sudah siap menghadapi lingkungannya, sehingga peran orang tua sangat penting dalam memberikan dasar-dasar pendidikan dan pengawasan yang ketat pada 
Pendas : Jurnal Ilmiah Pendidikan Dasar, ISSN Cetak : 2477-2143 ISSN Online : 2548-6950 Volume III Nomor 2, Desember 2018

anak. Hal tersebut bertolak belakang dengan karakteristik pola asuh permisif dimana orang tua pada pola asuh ini memberikan kebebasan pada anak untuk memonitor aktivitasnya sendiri. Pernyataan tersebut didukung oleh hasil screening awal, yaitu tidak adanya hasil yang mencapai kategori permisif (murni) diindikasikan dengan total skor hanya 40 poin diperoleh oleh siswa dengan pola asuh orang tua otoritatif cenderung permisif. Angka tersebut jauh di atas rentang skor pola asuh permisif (murni) yaitu 1-20 poin.

Selain menggunakan screening awal, pengambilan subjek penelitian juga diperkuat dengan pertimbangan atau arahan yang diberikan oleh narasumber yaitu wali kelas $3 \mathrm{~A}$, Ibu Ade Nining S.Pd. Sehingga berdasarkan hasil screening awal dan pertimbangan dari narasumber, peneliti mengambil 3 subjek penelitian yang menerapkan jenis pola asuh yang relevan dengan penelitian ini yaitu pola asuh otoritarian, pola asuh otoritatif, dan pola asuh otoritatif cenderung permisif. Adapun ketiga subjek terpilih yaitu Ibu Neny Angganingrum, Ibu Rini Dwi Astuti, dan Ibu Citra
Susanti dianggap layak untuk diteliti. Adapun karakteristik dari subjek penelitian tersebut adalah sebagai berikut:

Tabel 1

Subjek orang tua

\begin{tabular}{|c|c|c|c|c|}
\hline Nama & Umur & $\begin{array}{l}\text { Pendi } \\
\text { dikan }\end{array}$ & $\begin{array}{c}\text { Peker } \\
\text { jaan }\end{array}$ & $\begin{array}{l}\text { Pola } \\
\text { asuh }\end{array}$ \\
\hline $\begin{array}{c}\text { Neny } \\
\text { Anggani } \\
\text { ngrum }\end{array}$ & 29 th & SMA & $\begin{array}{l}\text { Wiras } \\
\text { wasta }\end{array}$ & $\begin{array}{c}\text { Otoritari } \\
\text { an }\end{array}$ \\
\hline $\begin{array}{c}\text { Rini Dwi } \\
\text { Astuti }\end{array}$ & $44 \mathrm{Th}$ & SMA & $\begin{array}{c}\text { Ibu } \\
\text { Ruma } \\
\text { h } \\
\text { Tangg } \\
\text { a }\end{array}$ & Otoritatif \\
\hline $\begin{array}{c}\text { Citra } \\
\text { Susanti }\end{array}$ & $32 \mathrm{Th}$ & SMK & $\begin{array}{c}\text { Ibu } \\
\text { Ruma } \\
\text { h } \\
\text { Tangg } \\
\text { a }\end{array}$ & $\begin{array}{c}\text { Otoritatif } \\
\text { cenderu } \\
\text { ng } \\
\text { permisif }\end{array}$ \\
\hline
\end{tabular}

Berdasarkan tabel di atas, dapat diketahui bahwa ketiga subjek penelitian terdiri dari ibu rumah tangga dan juga wiraswata, dan berada pada usia yang berbeda satu sama lain. Untuk menambah keakuratan data penelitian, peneliti mengambil data dari anak ketiga subjek penelitian di atas. Adapun identitas anak dari subjek penelitian terdiri dari 2 orang anak laki-laki dan seorang anak perempuan yang beragama islam dan berada pada rentang usia yang sesuai dengan tahap laten (latency stage) yaitu 5 -12 tahun. 
Pendas : Jurnal Ilmiah Pendidikan Dasar, ISSN Cetak : 2477-2143 ISSN Online : 2548-6950 Volume III Nomor 2, Desember 2018

Bentuk-bentuk pendidikan seks yang diterapkan pada masing-masing orang tua mengacu pada indikator penelitian yang dikemukakan oleh Chomaria (2012). Penerapan perlakuan mengenai pendidikan seks yang sesuai dengan indikator penelitian yaitu pertama, dalam memberikan perlakuan sesuai jenis kelamin serta menanamkan jiwa maskulinitas dan feminitas pada anak. Berdasarkan penelitian di lapangan, peneliti menemukan bahwa ketiga subjek penelitian mengajarkan hal tersebut kepada anak melalui pemberian nama, gaya rambut, dan cara berpakaian yang sesuai dengan jenis kelamin anak. Kedua, dalam mengenalkan bagian tubuh, fungsi, serta cara membersihkan bagian-bagian tubuh kepada anak. Hasil penelitian di lapangan menemukan ketiga subjek penelitian mengajarkan untuk tidak menyentuh, menggaruk, atau memperlihatkan alat kelaminnya didepan umum, serta mengajarkan cara membersihkan alat kelamin anak setelah membuang hajat dan mengganti pakaian dalam 2 kali sehari setelah mandi. Ketiga, dalam memberitahu jenis-jenis sentuhan serta bagian tubuh yang boleh dan tidak boleh disentuh. Berdasarkan hasil penelitian, perlakuan yang ditemukan di lapangan yaitu orang tua memperkenalkan aurat kepada anak, dua dari tiga subjek penelitian mengenalkan jenis sentuhan yang pantas atau tidak pantas dari orang lain, serta mengajarkan cara menolak sentuhan tersebut. Keempat, seleksi media yang dikonsumsi anak. Pada penelitian di lapangan ditemukan bahwa ketiga subjek penelitian menyeleksi dan mengawasi media, baik akses internet maupun acara televisi yang layak dikonsumsi anak.

Pola asuh pertama pada penelitian ini adalah pola asuh otoritarian. Berdasarkan hasil observasi peneliti di lapangan, terdapat beberapa indikator yang sesuai dengan karakteristik pola asuh orang tua tipe otoritarian dalam memberikan pendidikan seks tahap awal pada anak. Karakteristik tersebut yaitu pertama, orang tua otoritarian selalu mengontrol tingkah laku anak sesuai dengan standar yang telah ditetapkan. Hal tersebut terlihat pada kontrol yang dilakukan oleh Ibu Neny terhadap penggunaan internet dan acara televisi yang selalu di seleksi sebelum ditonton Azka juga 
Pendas : Jurnal Ilmiah Pendidikan Dasar, ISSN Cetak : 2477-2143 ISSN Online : 2548-6950 Volume III Nomor 2, Desember 2018

dalam mengontrol kebersihan tubuh dan kerapihan rambut.

Kedua, orang tua otoritarian selalu berusaha membuat anak mematuhi serangkaian standar perilaku yang telah ditentukan. Hal tersebut terlihat dari cara Ibu Neny menentukan pakaian yang harus dikenakan Azka meskipun sebelumnya Azka sudah memilih sendiri pakaian yang diinginkannya. Selain itu, Ibu Neny juga selalu mengingatkan azka untuk menjaga aurat serta mengajarkan cara menolak sentuhan-sentuhan yang tidak boleh diterimanya dari orang lain selain Ibu dan Ayahnya.

Ketiga, hubungan antara orang tua otoritarian dengan anak kurang hangat. Hubungan yang kurang hangat ini dikarenakan adanya standar-standar yang ditetapkan Ibu Neny kepada Azka, serta kebiasaan penggunaan nada tinggi ketika berbicara dengan Azka. Ibu Neny juga kerap kali meminta Azka untuk mematuhi keinginannya tanpa banyak bertanya.

Pola asuh otoritarian tentang pendidikan seks yang diberikan oleh Ibu Neny kepada Azka ini memiliki dampak positif dan negatif. Dampak positif yang timbul yaitu Azka tumbuh menjadi anak yang disiplin dalam menjaga kerapihan dan kebersihan dirinya. Azka juga dapat menghargai lawan bicaranya baik yang lebih dewasa maupun yang lebih muda, baik sesama maupun yang berlawanan jenis dengannya. Sedangkan dampak negatif dari pemberian pola asuh otoritarian yaitu Azka terlihat kurang puas dan sering memurungkan wajahnya karena seringkali hal yang dilakukannya bukanlah keinginannya sendiri melainkan keinginan orang tuanya, hal tersebut membuat Azka tidak dapat mengeksplor kemampuannya secara maksimal.

Pola asuh kedua pada penelitian ini adalah pola asuh otoritatif. Berdasarkan hasil observasi dan wawancara penelitian, terdapat beberapa karakteristik pola asuh orang tua tipe otoritatif dalam memberikan pendidikan seks tahap awal pada anak yang sesuai dengan hasil yang ditemukan di lapangan. Karakteristik tersebut yang pertama, orang tua otoritaif mau memandu anak dengan mengahargai keputusan dan kemampuan anak. Hal tersebut terlihat pada cara Ibu Rini yang menganjarkan cara membuang air kecil sesuai jenis kelamin anak, 
Pendas : Jurnal IImiah Pendidikan Dasar, ISSN Cetak : 2477-2143 ISSN Online : 2548-6950 Volume III Nomor 2, Desember 2018

dengan sabar dan telaten memandu anak agar dapat membuang air dengan benar tetapi juga mengharagai kemampuan anak ketika anak belum dapat membuang air sesuai jenis kelamin.

Kedua, orang tua otoritatif memberikan kebebasan pada anak namun menetapkan standar perilaku yang jelas pada anak. Hal tersebut terlihat pada cara Ibu Rini memberikan kebebasan untuk Adel dalam memilih sendiri pakaian yang ingin dikenakannya, namun dengan standar bahwa pakaian tersebut sopan dan rapi. Ketiga, orang tua otoritatif menjelaskan alasan dibalik pendapat mereka dan mengharapkan komunikasi timbal balik dalam keluarga.hal tersebut terlihat pada saat Ibu Rini menyeleksi acara TV yang layak dikonsumsi Adel, serta membuat ruang dalam media sosial untuk membiasakan anak selalu berkomunikasi dua arah dalam keluarga.

Sama seperti pola asuh otoritarian, penerapan pola asuh otoritatif tentang pendidikan seks yang disampaikan oleh Ibu Rini ini memiliki dampak bagi anak. Hasil observasi di lapangan, terlihat bahwa Adel dapat merasa puas dan mandiri karena dapat mengeksplorasi kemampuan atau keinginannya sendiri. Hal tersebut terlihat pada kemandirian Adel untuk memilih sendiri pakaian yang tepat untuk dikenakan di rumah maupun saat pergi keluar rumah. Adel juga tumbuh dengan perasaan aman dan dicintai karena orang tua tidak banyak menuntut serta menerapkan aturanaturan, memberikan perhatian secara wajar, serta menghargai kemampuan yang dimiliki oleh Adel.

Pola asuh terakhir. Atau pola asuh ketiga pada penelitian ini adalah pola asuh otoritatif cenderung permisif. Berdasarkan yang peneliti temui di lapangan dapat disimpulkan bahwa dalam memberikan pendidikan seks tahap awal kepada anak, Ibu Santi menyampaikannya dengan pola asuh otoritatif cenderung pemisif. Dimana karakteristik pola asuh otoritatif yang terlihat pada Ibu Santi adalah memandu anak tetapi juga menghargai keputusan dan kepribadian anak, dan mau menjelaskan alasan dibalik pendapatnya namun tetap meminta perilaku yang baik dari anak. hal tersebut terlihat ketika Ibu Santi memperbolehkan Ori memilih pakaian, serta mainan yang ingin di 
Pendas : Jurnal IImiah Pendidikan Dasar, ISSN Cetak : 2477-2143 ISSN Online : 2548-6950 Volume III Nomor 2, Desember 2018

inginkannya selama hal tersebut sesuai dengan jenis kelaminnya. Ibu santi juga dengan sabar memandu Ori untuk dapat membersihkan dan merawat sendiri kebersihan organorgan reproduksinya, Ibu Santi mengharapkan Ori dapat melakukannya dengan baik.

Sedangkan karakteristik pola asuh permisif yang terlihat pada Ibu Santi adalah kurangnya kontrol atau pengawasan pada anak, hubungan orang tua dan anak yang sangat dekat, dan jarang menghukum apabila anak melanggar peraturan atau berbuat kesalahan, serta menerima atau membiarkan perilaku anak yang buruk. Hal ini terlihat pada saat Ori terlihat bermain keluar rmah hanya dengan menggunakan handuk saja namun Ibu santi yang melihat hal tersebut tidak lantas memarahi ataupun memperingatkan perilaku Ori tersebut. Dengan demikian disimpulkan Ibu Santi kurang melakukan kontrol dan membiarkan anak untuk tidak menutup auratnya sendiri.

Melalui penelitian di lapangan, peneliti juga dapat melihat dampak yang terjadi pada Ori atas pemberian pola asuh otoritatif cenderung permisif oleh Ibu Santi. Dampak positif yang terlihat yaitu Ori terlihat lebih puas karena memiliki kebebasan untuk mengeksplorasi keinginannya sendiri. Ori juga mudah bergaul dan dapat menghargai teman sebaya karena rasa kepercayaan diri yang tumbuh dari perlakuan keluarganya.sedangkan dampak negatif yang terlihat pada Ori yaitu, Ori terlihat kurang dapat melakukan kontrol diri untuk menjaga auratnya. la juga kurang dapat mengatur waktu dengan baik, seperti menggunakan gadget selama berjam-jam. Hal tersebut dikonfirmasi peneliti karena peeneliti melihat Ori tidak pernah diingatkan untuk membuka atau mengulang kembali pelajaran sekolah oleh orangtuanya.

\section{E. KESIMPULAN}

Berdasarkan uraian hasil penelitian dan pembahasan mengenai Pola Asuh Orang Tua tentang pendidikan seks kepada siswa kelas 3 SD negeri Batu Ceper 01 Kota Tangerang, dapat disimpulkan bahwa melalui proses screening awal, ditemukan 18 orang tua menerapkan pola asuh otoritarian cenderung otoritatif, 5 orang tua menerapkan pola asuh otoritarian, 6 orang tua menerapkan pola asuh 
Pendas : Jurnal IImiah Pendidikan Dasar, ISSN Cetak : 2477-2143 ISSN Online : 2548-6950 Volume III Nomor 2, Desember 2018

otoritartif, dan 2 orang tua menerapkan pola asuh otoritatif cenderung permisif dan tidak ditemukannya pola asuh permisif (murni) dalam penelitian ini. Pendidikan seks pada tiga pola asuh, yaitu 1) Pola asuh otoritarian selalu mengontrol tingkah laku anak dan menuntut kepatuhan, 2) Pola asuh otoritatif mau memandu anak tetapi tetap memberi kebebasan berekspresi, 3) Pola asuh otoritarian cenderung permisif mau memandu anak tetapi kurang memberikan kontrol.

\section{DAFTAR PUSTAKA}

Abduh, M., \& Wulandari, M.D. (2016). Model Pendidikan Seks pada Anak Sekolah Dasar Berbasis Teori Perkembangan Anak. Jurnal. Fakultas Keguruan dan IImu Pendidikan. Surakarta: Universitas Muhammadiyah Surakarta.

Adiputra, Sofwan. (2011). ModelModel Analisis Data Kualitatif. Lingkaran Konseling Pusat Pembelajaran Bimbingan Dan Konseling.

https://bkpemula.wordpress.com /2011/12/04/model-modelanalisis-data-kualitatif/

Alimul, Aziz. (2009). Pengantar Kebutuhan Dasar Manusia (Aplikasi Konsep dan Proses Keperawatan). Jakarta: Salemba Medika.
Brahim, T.K., Abdullah, K., \& Hasan, N. (2015). Penelitian IImiah (Pengertian, Penerapan, Dan Pengetahuan Tambahan). Jakarta: Suara GKYE Peduli Bangsa.

Chomaria, Nurul. (2012). Pendidikan Seks untuk Anak. Solo: Aqwam.

Dariyo, Agus. (2013). Dasar-Dasar Pedagogi Modern. Jakarta: Indeks.

Diah, Nella. (2016). Tujuan Pengasuhan. Diary Bunda Nella.

http://diarybundanella.blogspot.c o.id/2016/12/tujuanpengasuhan.html.

Djamarah, S.B. (2014). Pola Asuh Orang Tua dan Komunikasi dalam Keluarga. Jakarta: Rineka Cipta.

Djamarah, S.B. (2011). Psikologi Belajar. Jakarta: Rineka Cipta.

Gunarsa, S. D. (2009). Dari Anak Sampai Usia Lanjut. Jakarta: Gunung Mulia.

Halimi. (2014). Penelitian Studi Kasus (Desain \& Metode). https://pascasarjanahalimi.blogspot.co.id/2014/12/pe nelitian-studi-kasus-desainmetode.html .

Icha. (2016). Pola Asuh Orang Tua dan Tujuannya. Rumah Bunda. http://www.rumahbunda.com/pa renting/pola-asuh-pada-anakdan-tujuannya/.

Lestari, E., \& Prasetyo, J. (2014). Peran Orang Tua dalam Memberikan Pendidikan Seks Sedini Mungkin di TK Mardisiwi Desa Kedondong Kecamatan Kebonsari Kabupaten Madiun. 
Pendas : Jurnal Ilmiah Pendidikan Dasar, ISSN Cetak : 2477-2143 ISSN Online : 2548-6950

Volume III Nomor 2, Desember 2018

Jurnal Ilmiah Pendidikan.

Magetan: Sekolah Tinggi

Keguruan dan IImu Pendidikan

Dr. Nugroho.

Mawardi. (2016). Modul Penelitian

Tindakan Kelas. Jakarta:

Universitas Muhammadiyah

Tangerang.

Nisak, H.K. (2013). Pola Asuh Orang

Tua dalam Menanamkan

Kedisiplinan Anak. Skripsi.

Fakultas IImu Pendidikan.

Semarang: Universitas Negeri

Semarang.

Novi. (2015). Tanya Jawab Seputar

Parenting (Masalah-Masalah

Umum Orang Tua dalam

Mendidik Anak). Yogyakarta:

Flashbooks.

Pandawa Care Foundation. (2016).

Pola Asuh Anak yang Efektif

dalam Keluarga. Pandawa Care

Foundation.

http://www.pandawacare.or.id/2

016/03/06/pola-asuh-anak-

yang-efektif-dalam-keluarga/.

Papalia, Olds, \& Feldman. (2008).

Perkembangan Manusia Edisi

10. Human Development Edisi

10 Jakarta: Salemba Humanika.

Santana, S. (2010). Menulis IImiah

Metodologi Penelitian Kualitatif

Edisi ke 2. Jakarta: Yayasan

Pustaka Obor Indonesia.

Susanto, Ahmad. (2016). Teori Belajar dan Pembelajaran di Sekolah Dasar. Jakarta: Kencana Prenadamedia Group.

Sugiyono. (2014). Cara Mudah Menyusun: Skripsi, Tesis, dan Disertasi. Bandung: Alfabeta.

Wiendijarti, Ida. (2011). Komunikasi Interpersonal Orang Tua dan
Anak dalam Pendidikan

Seksual. Jurnal IImu

Komunikasi. Program Studi IImu

Komunikasi. Yogyakarta:

Universitas Pembangunan

Nasional 'Veteran'.

Winarti. (2011). Pengaruh Pola Asuh Orang Tua dalam Pembentukan Akhlak Anak Usia 7-12 Tahun di Ketapang Tangerang. Skripsi. Fakultas IImu Dakwah dan IImu Komunikasi. Jakarta: Universitas Islam Negeri Syarif Hidayatullah. 